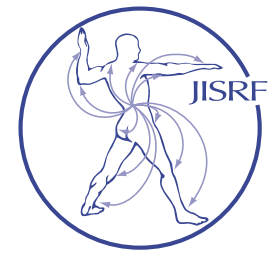

Check for updates

\title{
Exploration of Serum 25-hydroxy Vitamin D in Total Joint Arthroplasty Within a Subtropical Climate
}

Naylor $B^{1}$, King $A^{2}$, Voges $S^{2}$, Blackwell $T^{2}$, Huff $R^{2}$, Schutte $H^{2}$

\section{Abstract}

Background: The importance of appropriate serum 25-hydroxy vitamin D [25(OH)D] for multiple health measures is widely described, however, the prevalence of vitamin D deficiency remains remarkably high. The goal of our study is to explore the distribution of vitamin D deficiency among an elective total joint arthroplasty (TJA) population within a lower latitude climate with relatively abundant sunshine. We hypothesize this group will demonstrate a high prevalence of vitamin D deficiency, thus exposing a potential opportunity to improve outcomes with proper identification and management.

Methods: From January to December, 2014, serum $25(\mathrm{OH}) \mathrm{D}$ levels were collected during a standard preoperative workup prior to primary or revision joint arthroplasty in South Carolina. Mean serum 25(OH)D, seasonal variation, and patient demographics were recorded. We defined Vitamin D deficiency consistent with the current Endocrine Society classification: serum $25(\mathrm{OH}) \mathrm{D}<20 \mathrm{ng} / \mathrm{ml}$, 21-29 ng/ml, and 30-100 ng/ml representing deficiency, insufficiency, and normal, respectively.

Results: A total of 308 patients underwent evaluation. $46.8 \%$ (144) of the participants were female, and $89.6 \%$ (276) identified as Caucasian. The mean patient age was 68.3 years \pm 13.8 (32-88). The average serum $25(\mathrm{OH}) \mathrm{D}$ was $29.8 \mathrm{ng} / \mathrm{ml} \pm 12.8$ (5.1-79.9), with only $46.2 \%$ of patients having a normal serum $25(\mathrm{OH}) \mathrm{D}(\mathrm{p}<0.0001)$. Caucasian and non-white patients averaged $33 \mathrm{ng} / \mathrm{ml}[56 \%$ normal $25(\mathrm{OH}) \mathrm{D}]$ and $25 \mathrm{ng} / \mathrm{ml}[36 \%$ normal $25(\mathrm{OH}) \mathrm{D}]$, respectively $(\mathrm{p}=0.22)$. Patients over the age of $65 \mathrm{dem}$ onstrated lower serum $25(\mathrm{OH}) \mathrm{D}(28.5 \mathrm{ng} / \mathrm{ml})$ compared to those under $65(30.7 \mathrm{ng} / \mathrm{ml})(\mathrm{p}=.12)$. As expected, serum $25(\mathrm{OH}) \mathrm{D}$ demonstrated variation throughout the year: January to March, April to June, July to September, and October to December recorded $28.5 \mathrm{ng} / \mathrm{ml}, 31.73 \mathrm{ng} / \mathrm{ml}, 36.57$ $\mathrm{ng} / \mathrm{ml}$, and $23.03 \mathrm{ng} / \mathrm{ml} 25(\mathrm{OH}) \mathrm{D}$, respectively.

Conclusion: The majority $(53.8 \%)$ of an otherwise classically low risk patient population present with vitamin D insufficiency or deficiency prior to undergoing elective total joint arthroplasty, with elderly non-white patients in the winter months at the highest risk. Appropriate vitamin D management is associated with favorable influences on both skeletal and non-skeletal outcomes. Potential complications of total joint arthroplasty (TJA), including periprosthetic joint infection and aseptic loosening, can possibly be decreased with proper identification and treatment, which can be elucidated by future high quality studies.

\section{Background}

Genetic evolution has struggled to keep pace with the gradual decline in abundant sun exposure that cloaked our distant ancestors. Consequently, the ultraviolet dependent

Keywords: Adult reconstruction, basic science, osteoporosis, total joint arthroplasty

Level of Evidence: AAOS Therapeutic Level III

Educational Value \& Significance: JISRF Level B 
metabolism of vitamin D, or "sunshine vitamin," has been challenged. [1,2] Historic vitamin D recommendations unfortunately reflect only the modern "normal" reference range for serum 25-hydroxy vitamin D [25(OH)D]. []ㅡ Those who spend a significant amount of time outdoors, for example, farmers and construction workers, likely reflect a true physiologic normal reference range; a range humans evolved to optimally function within. Popular recommendations regarding sunscreen, skin coverage, and sun avoidance have further discouraged our natural vitamin D synthesis. Many experts now believe moderate sun exposure, or heliotherapy, should be sought rather than avoided, with beneficial influences on blood pressure, general well-being, and balancing the sleep-wake cycle. $[1,4]$ However, controlled sun exposure is an unreliable means of generating adequate synthesis of this unique vitamin. Regional variations in climate and cultural practices can significantly impact serum $25(\mathrm{OH}) \mathrm{D}$. Even in temperate climates like Honolulu, Hawaii, over half of otherwise healthy patients have demonstrated sub-optimal vitamin D indices. [ $[\underline{]}]$

The importance of appropriate serum $25(\mathrm{OH}) \mathrm{D}$ on multiple health measures is widely described. Vitamin D supplementation reveals direct dose-response improvements in bone mineral density, fracture prevention, and lower extremity strength and function. [ $\underline{3}, \underline{4}, \underline{6}, \underline{7}]$ A serum $25(\mathrm{OH})$ $\mathrm{D}$ within normal limits is associated with a decreased risk of microbial infections, falls, numerous cancers, multiple sclerosis, cardiovascular disease, autoimmune diseases, and diabetes mellitus. [ $\underline{6}-\underline{10}]$ Standardized management of vitamin D deficiency could potentially have profound effects on health care costs and morbidity related to countless chronic diseases. [무, 11$]$

The high prevalence of vitamin D deficiency in those undergoing orthopedic surgery is well described. [12] However, limited studies exist documenting vitamin D deficiency in the elective arthroplasty group, particularly in a subtropical climate. The goal of our study is to explore the prevalence and distribution of vitamin $\mathrm{D}$ deficiency among an elective total joint arthroplasty (TJA) population within a lower latitude climate with relatively abundant sunshine. We hypothesize a continued high prevalence of vitamin D deficiency within this population, exposing a potential opportunity to improve outcomes with proper management.

\section{Materials and Methods}

From January to December, 2014, serum 25(OH)D levels were collected during a standard preoperative workup prior to primary or revision joint arthroplasty by the senior author (H.D.S.) in South Carolina. Mean serum 25(OH)D, seasonal variation, and patient demographics were recorded. We defined Vitamin D deficiency consistent with the current Endocrine Society classification: serum 25(OH)D $<20 \mathrm{ng} / \mathrm{ml}, 21-29 \mathrm{ng} / \mathrm{ml}$, and 30-100 ng/ml representing deficiency, insufficiency, and normal, respectively. Posttraumatic primary joint replacement and revision secondary to periprosthetic joint infection (PJI) were excluded to limit confounding variables. The association between vitamin D classification and study group was tested with Fisher's exact test. Non-parametric Mann Whitney Wilcoxon tests with t-approximation two-tailed tests were used for intergroup comparisons.

\section{Results}

A total of 308 patients underwent evaluation. $46.8 \%$ (144) of the participants were female, and $89.6 \%$ (276) identified as Caucasian. The mean patient age was 68.3 years $( \pm 13.8,32-88)$. The average serum $25(\mathrm{OH}) \mathrm{D}$ was $29.8 \mathrm{ng} / \mathrm{ml}( \pm 12.8,5.1-79.9)$, with only $46.2 \%$ of patients having a normal serum $25(\mathrm{OH}) \mathrm{D}(\mathrm{p}<0.0001)$. Caucasian and non-white patients averaged $33 \mathrm{ng} / \mathrm{ml}$ [56\% normal $25(\mathrm{OH}) \mathrm{D}]$ and $25 \mathrm{ng} / \mathrm{ml}[36 \%$ normal $25(\mathrm{OH}) \mathrm{D}]$, respectively, however this was not significant $(\mathrm{p}=0.22)$ (figure 1). Patients over the age of 65 demonstrated slightly lower

\section{Caucasian and Non-White 25(OH)D}

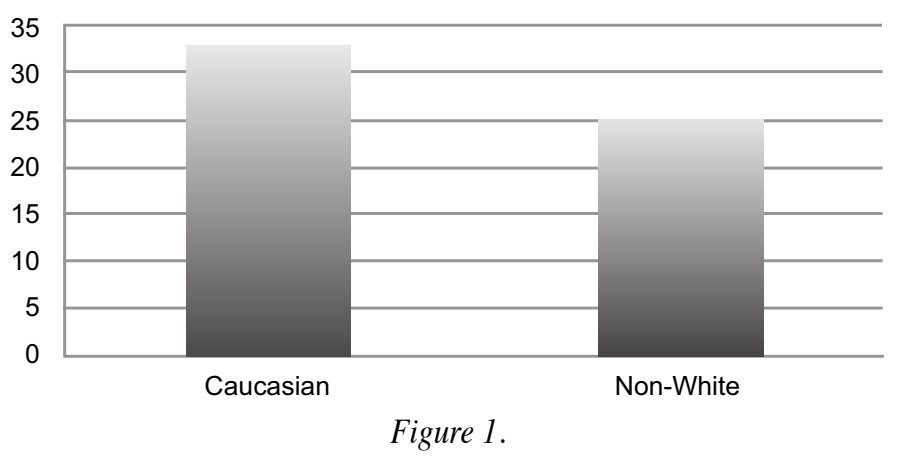

\section{Quarterly serum 25(OH)D}

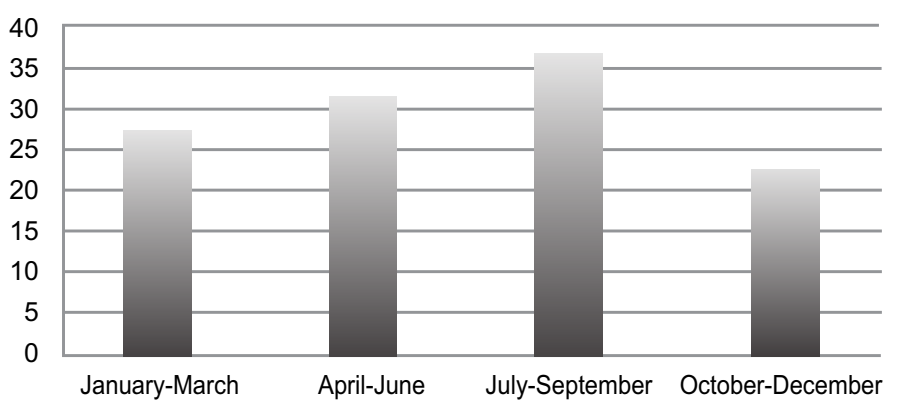

Figure 2.

Serum 25-hydroxy vitamin D [25(OHD] recorded as "ng/ml.” 
serum $25(\mathrm{OH}) \mathrm{D}(28.5 \mathrm{ng} / \mathrm{ml})$ compared to those under 65 $(30.7 \mathrm{ng} / \mathrm{ml})(\mathrm{p}=.12)$. As expected, serum $25(\mathrm{OH}) \mathrm{D}$ demonstrated variation throughout the year: January to March, April to June, July to September, and October to December recorded $28.5 \mathrm{ng} / \mathrm{ml}, 31.73 \mathrm{ng} / \mathrm{ml}, 36.57 \mathrm{ng} / \mathrm{ml}$, and 23.03 $\mathrm{ng} / \mathrm{ml} 25(\mathrm{OH}) \mathrm{D}$, respectively (figure 2). July recorded the highest monthly average serum $25(\mathrm{OH}) \mathrm{D}$ with $40.11 \mathrm{ng} /$ $\mathrm{ml}$, while February recorded the lowest reaching $25.2 \mathrm{ng} /$ $\mathrm{ml}$.

\section{Discussion}

Our results demonstrate the majority $(53.8 \%)$ of an otherwise classically low risk population based on latitude [13] and race [14] present with at least vitamin D insufficiency prior to undergoing elective total joint arthroplasty. Our findings reinforce previous findings regarding seasonal variations in serum $25(\mathrm{OH}) \mathrm{D}$. [15] Additionally, while not significant, our findings lend support to the well described natural physiologic age dependent decline in serum $25(\mathrm{OH}) \mathrm{D}$. [16] Non-white patients over 65 years of age during the winter months were at the greatest risk of vitamin $\mathrm{D}$ deficiency.

A majority of patients undergoing elective orthopedic surgery have demonstrated vitamin D insufficiency, with orthopedic trauma patients at a higher risk. $[\underline{9}, \underline{12}]$ One study reported $77.7 \%$ of hip fracture patients had sub-normal serum $25(\mathrm{OH}) \mathrm{D}$ versus $58.6 \%$ in normal controls. [17] Furthermore, periprosthetic joint infections (PJI) show a close association with vitamin D deficiency in the arthroplasty population. [9] Emerging evidence also suggests vitamin D plays a significant role in antimicrobial activity. $[\underline{7}, \underline{8}, \underline{18}, \underline{19}]$ Numerous advantages of maintaining appropriate serum $25(\mathrm{OH}) \mathrm{D}$ continue to emerge, however, appropriate management remains controversial. $[\underline{7}, \underline{18}, \underline{20}, \underline{21}]$ Multiple dosing protocols have been evaluated. $[\underline{20}, \underline{21}]$ One study suggested daily requirements of at least 1,600 IU D3 for optimal serum levels. [21] This dose was further analyzed in a randomized placebo control trial, where the mean serum $25(\mathrm{OH}) \mathrm{D}$ increased from $20.6 \mathrm{ng} / \mathrm{ml}$ to $33.7 \mathrm{ng} / \mathrm{ml}$ in the treatment group, but declined to $18.5 \mathrm{ng} /$ $\mathrm{ml}$ in the control group. [20] However, while encouraging, these findings suggest that even 1,600 IU D3 daily may fail to achieve the optimal serum threshold. Load and maintenance dosing is recommended when deficiency is identified. $[10,22]$ Bolus dosing as high as 500,000 IU D3 with maintenance doses of 50,000 IU D3 monthly have demonstrated safe and rapid serum 25(OH)D normalization. Many experts believe $30 \mathrm{ng} / \mathrm{mL} 25(\mathrm{OH}) \mathrm{D}$ reflects a minimum threshold for both skeletal and non-skeletal benefits, with an optimal range between 36 and $40 \mathrm{ng} / \mathrm{ml}$. [20-4, $\underline{20}-$ 22] The Endocrine Society recommends 1500-2000 IU D3 daily to meet these goals, and 50,000 IU D2 or D3 weekly for 8 weeks is recommended when deficiency is identified. [10]

Surgical site infections (SSIs) in the setting of TJA can have catastrophic consequences. [를 The vitamin D pathway is intimately involved in antimicrobial activity through both the innate and acquired immune response. $[\underline{8}, \underline{19}]$ For example, interferon-gamma (IFN-y), a key antimicrobial mediator, is only induced in vitamin D-sufficient sera, with vitamin D receptor (VDR) induction required for antimicrobial peptide expression. []] Additionally, tolllike receptors (TLRs), a key mediator of the innate immune system, demonstrate a key interplay with the vitamin D pathway. [19] Human macrophages appear to up-regulate VDR and vitamin D-1-hydroxylase genes inducing antimicrobial peptides like cathelicidin to eradicate microbial infections. Compared to Caucasian sera, AfricanAmerican sera demonstrate significantly lower cathelicidin induction and antimicrobial peptide expression. Vitamin D supplementation for one year in both African-Americans and Caucasians in one study corrected the serum $25(\mathrm{OH}) \mathrm{D}$ discrepancy (24.1 ng/ml versus $37.2 \mathrm{ng} / \mathrm{ml}$ ) after just two months of treatment, reaching a final $67.7 \mathrm{ng} / \mathrm{ml}$ and 67.3 $\mathrm{ng} / \mathrm{ml}$ at one year, respectively. [2] Furthermore, a significantly higher prevalence of vitamin D deficiency was found in patients undergoing revision TJA for PJI compared to both primary TJA and aseptic loosening revision groups, with $13.29 \mathrm{ng} / \mathrm{ml}$ versus $20.52 \mathrm{ng} / \mathrm{ml}$, respectively. [2] Interestingly, serum $25(\mathrm{OH}) \mathrm{D}$ shows an inverse relationship with C-reactive protein, although the significance of this relationship is not completely understood. [12,24]

As a cross sectional analysis, this study has several inherent limitations. First, we are unable to assess specific trends in serum 25(OH)D. Therefore, perioperative and long term outcomes associated with specific serum $25(\mathrm{OH})$ $\mathrm{D}$ are not revealed. In a addition, specific comorbidities and preoperative vitamin supplementation were not recorded. Our population was also largely Caucasians, which may have substantial influences on the generalizability of our findings. Other modes of diagnosis and treatment including intact vitamin D [1] ] and 25(OH)D3 (HyD) [7] are on the horizon and show encouraging results. Further research is needed to investigate the association between vitamin D deficiency, appropriate treatment thresholds, and specific orthopedic outcomes. Current evidence supports normalizing Vitamin D levels in the perioperative period with potentially reduced patient length of stay and SSIs in the orthopedic population. [25] At our institution we have developed a perioperative protocol based on a pre- 
operative serum $25(\mathrm{OH}) \mathrm{D}$ evaluation. Those with serum $25(\mathrm{OH}) \mathrm{D}$ under $35 \mathrm{ng} / \mathrm{ml}$ receive 5,000 IU D3 daily beginning 2 weeks prior to surgery, with re-evaluation the day of surgery. Patients with a serum $25(\mathrm{OH}) \mathrm{D}<30 \mathrm{ng} / \mathrm{ml}$ the day of surgery receive 50,000 IU D2 weekly for 8 weeks, followed by 2000 IU D3 daily indefinitely. Endocrinology referral is warranted for continued vitamin D deficiency.

\section{Conclusion}

Our results demonstrate the majority (53.8\%) of an otherwise classically low risk patient population present with at least vitamin D insufficiency prior to undergoing elective total joint arthroplasty, with elderly non-white patients in the winter months at the highest risk. Appropriate vitamin D management is associated with favorable influences on both skeletal and non-skeletal outcomes. Potential complications of TJA, including periprosthetic joint infection and aseptic loosening, can possibly be decreased with proper identification and treatment. Appropriately designed studies are needed to fully elucidate the importance of vitamin $\mathrm{D}$ in short and long term outcomes within the total joint arthroplasty population.

\section{References:}

1. Baggerly CA, Cuomo RE, French CB, et al. Sunlight and Vitamin D: Necessary for Public Health. Journal of the American College of Nutrition. 2015; 34 (4): 359-365

2. Garrett-Mayer E., Wagner CL, Hollis BW, et al. Vitamin D3 Supplementation (4000 IU/d for $1 \mathrm{y}$ ) eliminates differences in circulation 25-hodroxyvitamin D between African American and white men. The American Journal of Clinical Nutirition. 2012; 96: 332-336.

3. Hollis BW .Circulating 25-Hydroxyvitamin D Levels Indicative of Vitamin D Sufficiency: Implications for Establishing a New Effective Dietary Intake Recommendation for Vitamin D. The Journal of Nutrition. 2005; 135: 317-322.

4. Vieth R. What is the optimal vitamin D status for health? Progress in Biophysics and Molecular Biology. 2006; 92: 26-32.

5. Binkley N, Novotny R, Krueger D, et al. Low Vitamin D Status despite Abundant Sun Exposure. The Journal of Clinical Endocrinology \& Metabolism. 2007; 92 (6):2130-2135.

6. Bishcoff-Ferrari HA, Giovannucci E, Willett WC, et al. Estimation of optimal serum concentrations of 25-hydroxyvitamin $\mathrm{D}$ for multiple health outcomes. The Am Journal of Clinical Nutrition. 2006; 84: 18-28.

7. Bischoff-Ferrari HA, Dawson-Hughes B, Stocklin E, et al. Oral Supplementation With $25(\mathrm{OH})$ D3 Versus Vitamin D3: Effects on 25(OH) D Levels, Lower Extremity Function, Blood Pressure, and Markers of Innate Immunity. Journal of Bone and Mineral Research. 2012; 27(1): 160-169.

8. Fabri M, Stenger S, Shin D, et al. Vitamin D is Required for IFN-Mediated Antimicrobial Activity of Human Macrophages. Science Translation Medicine. 2011; 3 (104): 1-10.

9. Maier GS, Horas K, Seeger JB, et al. Is There an Association Between Periprosthetic Joint Infection and Low Vitamin D Levels. International Orthopaedics. 2014; 38 (7): 1499-1504

10. Holick MF, Binkley NC, Bischoff-Ferrari HA, et al. Evaluation, Treatment, and Prevention of Vitamin D Deficiency: An Endocrine Society Clinical Practice Guideline. The Journal of Clinical Endocrinology \& Metabolism, 2011; 96 (7): 1911-1930.

11. Grant W, Schuitemaker GE. Health benefits of higher serum 25-hydroxyvitamin D levels in The Netherlands. Journal of Steroid Biochemistry and Molecular Biology. 2012; 121: 456-458
12. Waldron JL, Ashby HL, Cornes MP, et al. Vitamin D: A negative acute phase reactant. Journal of Clinical Pathology. 2013; 66: 620-622

13. Leary PF, Zamfirova I, Au J, et al. Effect of Latitude on Vitamin D Levels. The journal of the American osteopathic association. 2017;117:433-439.

14. Harris SS. Vitamin D and African Americans. Journal of Nutrition. 2006. 136, 4 1126-1129.

15. Levis S, Gomez A, Jiminez C, et al. Vitamin D deficiency and seasonal variation in an adult South Florida population. The J. of Clin Endocin \& Metabolism 2005;90(3):1557-1562

16. Gallagher JC. Vitamin D and Aging. Endocrinology and metabolism clinics of North America. 2013;42(2):319-332.

17. Wang X, Yang B, Wang Y, et al. Serum Levels of 25-hydroxyvitamin D and Functional Outcome in Older Patients with Hip Fracture. Journal of Arthroplasty. 2014; 30: 891-894.

18. Hollis BW, Wagner CL. The Role of the Parent Compoud Vitamin D with Respect to Metabolism and Function: Why Clinical Dose Intervals Can Affect Clinical Outcomes. The Journal of Clinical Endocrinology \& Metabolism. 2013; 98 (12): 4619-4628.

19. (16)Liu PT, Stenger S, Li H, et al. Toll-Like Receptor Triggering of a Vitamin DMediated Human Antimicrobial Response. Science. 2006; 311: 1770-1773.

20. Toss $\mathrm{G}$. Is a daily supplementation with 40 microgram vitamin D3 sufficient? A randomized controlled trial. European Journal of Nutrition. 2012; 51: 939-945.

21. Cashman D, Hill TR, Lucey AJ, et al. Estimation of the dietary requirement for vitamin D in healthy adults. The American Journal of Clinical Nutrition. 2008 88: $1535-1542$.

22. Bacon CJ, Gamble GD, Horne AM, et al. High-dose oral Vitamin D3 supplementation in the elderly. Osteoporosis International. 2009; 20: 1407-1415.

23. Pulido L, Ghanem E, Joshi A, Purtill JJ, Parvizi J. Periprosthetic Joint Infection: The Incidence, Timing, and Predisposing Factors. Clinical Orthopaedics and Related Research. 2008;466(7):1710-1715. doi:10.1007/s11999-008-0209-4.

24. Chandler PD, Scott JB, Drake BF, et al. Impact of Vitamin D Supplementation on Inflammatory Markers in African Americans: Results of a Four-Arm Randomized, Placebo-Controlled Trial. American Association for Cancer Research. 2013; 7 (2): 218-225.

25. Myint MW, Wu J, Wong E, Chan SP, et al. Clinical benefits of oral nutritional supplementation for elderly hip fracture patients: a single blind randomized controlled trial. Age and Aging. 2012; 42: 39-45.

\section{SUBMISSION HISTORY}

Submitted June 16, 2017

Reviewed August 21, 2017

Revised September 8, 2017

Accepted September 11, 2017

Published September 30, 2017

AUTHOR AFFILIATIONS

1 Brandon Naylor, D0

Mercy Health Department of Orthopedics, 2213 Cherry St Toledo, OH 43608

2 Amy King, APRN,MSN; Sarah Voges, APRN,MSN; Terry Blackwell PA; Robin Huff, BS; Harold "Del" Schutte, Jr., MD

East Cooper Medical Center, 2000 Hospital Drive, Mt Pleasant, SC 29464

(Direct inquires to Brandon Naylor, Naylor.brandon@gmail.com)

AUTHOR DISCLOSURES

The authors declare that there are no disclosures regarding the publication of this paper.

\section{COPYRIGHT \& OPEN ACCESS}

(c) 2017 Head, Nelson, Dyball, Lawrence. All rights reserved. Authors retain copyright and grant the journal right of first publication with the work. Reconstructive Review is an open access publication and follows the Creative Commons AttributionOPEN ACCESS NonCommercial CC BY-NC. This license allows anyone to download works, build upon the material, and share them with others for non-commercial purposes as long as they credit the senior author, Reconstructive Review, and the Joint Implant Surgery \& Research Foundation (JISRF). An example credit would be: "Courtesy of (senior author's name), Reconstructive Review, JISRF, Chagrin Falls, Ohio". 